\title{
ARCHEOLOGICZNA STRUKTURA ZBIORÓW CERAMIKI $Z$ OSAD NEOLITYCZNYCH
}

\author{
ARCHAEOLOGICAL COMPOSITION OF POTTERY ASSEMBLAGES \\ FROM NEOLITHIC SETTLEMENTS
}

\author{
Stanisław Kukawka \\ Instytut Archeologii, Uniwersytet Mikołaja Kopernika \\ ul. Szosa Bydgoska 44/48, 87-100 Toruń, Poland
}

\begin{abstract}
The article is intended to address an essence of pottery assemblages from Neolithic settlements. Three aspects have been analysed: relationships between complete vessels and fragments resulted from their breakage; relationship between composition of pottery vessels used at any given moment and composition of deposited ceramics; and relationship between deposited pottery and its excavated fraction. It is argued that pottery assemblages excavated and analysed by archaeologists are result of refuse practices. Consequently, they distinctive traits reflect neither a deposited assemblage nor a composition of pottery vessels used at any given moment at the settlement.
\end{abstract}

\section{ZARYSOWANIE PROBLEMU}

Ceramika naczyniowa, sądząc ze skali poświęcanego jej miejsca w publikacjach, stanowi dla archeologów źródło szczególnie wartościowe. Dotyczy to wszystkich okresów od neolitu począwszy, a na średniowieczu skończywszy. Zapewne podstawową ku temu przyczyną jest masowość i różnorodność znalezisk ceramicznych. Istnieje też przekonanie o ich szczególnych walorach poznawczych. Warto wspomnieć, że to właśnie ceramika stanowi podstawę archeologicznych podziałów kulturowych i wewnątrzkulturowych (grupy terytorialne, fazy rozwojowe), którym często, świadomie lub nieświadomie, przypisuje się walor realności kulturowej, a niekiedy i etnicznej. Choć dotyczy to także badaczy neolitu, najbardziej spektakularnego przykładu dostarcza tu archeologia wczesnego średniowiecza, gdzie wprost mówi się o ceramice słowiańskiej.

Archeolodzy analizują i opisują pozyskane podczas wykopalisk zespoły ceramiki. W opisach prezentują, które stany cech lub jakie ich konfiguracje zaobserwowali (analiza jakościowa) oraz jaką frekwencję mają one w zbiorze (analiza ilościowa). Zaprezentowane $w$ ten sposób informacje dotyczące cech technologii, morfologii i zdobnictwa 
mniej lub bardziej zadowalająco charakteryzują wydobytą na światło dzienne ceramikę. Pojawia się tu jednak problem, czy charakterystyki archeologiczne odnieść można do czasów pradziejowych, który postaram się naświetlić.

Oczywiście, na postawione wyżej pytanie natychmiast można udzielić odpowiedzi negatywnej. Receptury wytwórcze badane przez archeologa nie są zgodne $z$ całoksztaltem czynności wytwórców. Chodzi tu o kategorie poszczególnych cech i ich wewnętrznych stanów identyfikowanych przez wytwórcę i przez badacza. Chodzi też o problem szerszy. Rzeczywiste receptury wytwórcze zależne były od przekonań wytwórcy różniących się od przekonań badacza. Proces wytwórczy wiązał się też z zachowaniami, które my uznalibyśmy za irracjonalne bądź tylko zbędne dla powstania naczynia o konkretnych cechach fizycznych. W skład receptur wchodziły zapewne i takie elementy, jak właściwy czas i miejsce, wykonywane gesty, wypowiadane słowa, pewne czynności technologiczne z naszego punktu widzenia nieistotne, zakazy równoczesnego wykonywania pewnych czynności itp. Analizując ceramikę pradziejową, tego typu elementów uchwycić nie możemy i chcąc nie chcąc musimy się z tym pogodzić. Podobnie nie poznamy niematerialnych cech pojemników ceramicznych, a mamy powody, by przypuszczać, że naczynia nacechowane były właściwościami szczególnymi (np. sprawczymi) ${ }^{1}$.

Postawmy nasz problem nieco inaczej. Wyobraźmy sobie, że mamy możność wkroczenia do funkcjonującej dawnej osady, by skonfiskować wszelkie znajdujące się tam w użyciu naczynia. Mamy zatem możliwość przeanalizowania ich zgodnie z ustaloną metodą badawczą i zaprezentowania wyników zarówno jakościowych, jak i ilościowych. Rzecz jasna wehikułu czasu nie zbudujemy i nie przeprowadzimy analizy i opisu zarekwirowanej ceramiki. Warto się jednak zastanowić, czy charakterystyka źródeł ceramicznych pozyskanych metodą archeologiczną może być zbliżona do tej dokonanej po naszej wyimaginowanej konfiskacie? Czy realny zestaw naczyń znajduje dobre odzwierciedlenie w strukturze znalezisk archeologicznych?

Chcąc odpowiedzieć na tak postawione pytania rozpatrzę trzy zasadnicze aspekty zagadnienia, które ujać można w formie pytań:

1. W jakim stopniu charakterystyka zespołu całych naczyń odpowiada charakterystyce fragmentów powstałych po ich potłuczeniu?

2. W jakim stopniu fragmenty użytkowanych jednorazowo naczyń odpowiadają w swej charakterystyce fragmentom zdeponowanym w osadzie?

3. W jakim stopniu fragmenty zdeponowane w osadzie w swej charakterystyce odpowiadają fragmentom wydobytym przez archeologa?

$\mathrm{W}$ archeologii polskiej zasadniczo brak refleksji nad tak postawionymi pytaniami. Odnieść można wrażenie, że autorzy prezentujący ceramiczne źródła archeologiczne są przekonani, że opisują rzeczywistość pradziejową ${ }^{2}$. Przypuszczenie takie pogłębiają

Na przykład zauważa się ,,kulturowo ukształtowaną tendencję Indoeuropejczyków do uznawania naczyń za obiekty obdarzone wartościami z naszego punktu widzenia pozautylitarnymi" (K ow a I s k i 2000, s. 153).

${ }^{2}$ Wykładnię metodologiczną takiego rozumowania podaje B. Stolpiak. przyjmując czynnościową koncepcję kultury. W takim ujęciu „obserwacja archeologiczna nastawiona będzie na rejestrowanie cech wytworów i relacji występujących między wytworami będącymi oznakami czynności kulturowych”. Proponuje się tu 
dokonywane analizy ilościowe wewnętrznej struktury zbiorów, rozbudowane analizy porównawcze, niekiedy wspierane mniej lub bardziej wybujałą statystyką mającą obiektywizować naszą wiedzę ${ }^{3}$. Tymczasem sądy takie nie są prawdą. Stwierdzenie to wypływa nie tylko z powodów już opisanych, tzn. z faktu, że badane cechy ceramiki i ich stany powołali badacze, a nie wytwórcy, i że w skład receptur wytwórczych wchodzić mogły zachowania, których nie jesteśmy w stanie odkryć, gdyż materialnych śladów w ceramice nie pozostawiły. Nasza niemoc wczucia się w rolę wytwórcy jest oczywistością. To stąd wypracowane metody analizy i opisu ceramiki są wyłącznie narzędziem badawczym $^{4}$. W prezentowanym tekście chodzi raczej o to, że stosowanie tego narzędzia w odniesieniu do archeologicznych zbiorów ceramiki nie może być traktowane jako adekwatne do zastosowania tego narzędzia względem zespołów naczyń użytkowanych przez grupę ludzi w pradziejach. Inaczej mówiąc, na przykład ilościowa dominacja wyróżnionej grupy technologicznej, formy naczynia czy zdobienia nie odzwierciedla takiej dominacji w życiu dawnych wspólnot.

Uwagi, które tu prezentuję, są efektem rozważań nad ceramiką neolityczną z moich badań. Stąd też tytuł artykułu odnoszący się do neolitu. Precyzyjniej powinien się on odnosić do neolitu bądź raczej do kultury pucharów lejkowatych na Niżu Polskim. Sądzę jednak, że rozważania zawarte $w$ tym artykule odnoszą się do neolitu czy wręcz pradziejów w ogóle.

\section{CALE NACZYNIA A STEUCZKA CERAMICZNA}

Nie ulega wątpliwości, że naczynia użytkowane były w różnych celach. W związku z tym różniły się wielkością, kształtami, cechami technologicznymi oraz „dekoracją". Nie oznacza to, by dla nas identycznie wyglądające naczynia nie mogły służyć różnym celom, takim samym celom czy wreszcie, by jedno naczynie nie mogło pełnić różnych funkcji. Chodzi o to, że zestaw użytkowanych naczyń był zróżnicowany i że główną tego przyczyną były kulturowo uwarunkowane odmienności funkcjonalne. Po pothuczeniu takiego serwisu, w charakterystyce kompletu fragmentów powinniśmy zidentyfikować poszczególne stany cech. Ich frekwencje zidentyfikowane w zbiorze skorup mogą niekiedy znacznie odbiegać od struktury obserwowalnej w zespole całych naczyń. Jest to efekt

„rekonstruowanie czynności kulturowych wespól z ich wytworami” (S tolpiak 1988, s. 11, 12). Zatem archeologiczna rejestracja cech technologicznych i stylistycznych ceramiki traktowana jest obiektywnie $i$ tożsamo z poglądami wytwórcy. W przeciwnym bowiem razie owo „rekonstruowanie czynności kulturowych” w ogóle nie jest możliwe.

${ }^{3}$ Warto tu wskazać na przykład na opracowanie M. Nowaka, w którym liczba tabel i wykresów przekracza możliwości percepcyjne czytelnika i traktowana być może jedynie jako zbędna próba unaukowienia i obiektywizacji podanych w tekście treści (Nowak 1996).

${ }^{4}$ Jest to ujęcie zbliżone do poglądów na przykład A. Mierzwińskiego, który wyznaje: „Ceramika nie była i nie jest dla mnie ani źródłem, ani przedmiotem poznania. [...] Jest ona wyłącznie jednym z wielu środków służących kreowaniu własnej refleksji na temat jej wytwórców i użytkowników" (M i e r z w iński 2002, s. 72). 
przede wszystkim znacznego zróżnicowania wielkości potłuczonych naczyń i zróżnicowanego ich rozdrobnienia. Rozbieżności dotyczyć będą zarówno cech technologicznych, jak i zdobniczych czy morfologicznych.

Weźmy przykład dwóch naczyń wykonanych w różnych recepturach technologicznych. W zbiorze takim każda cecha technologiczna może mieć najwyżej dwa stany, a frekwencja każdego stanu dowolnej cechy może wynosić 100 albo $50 \%$. Jednocześnie istnieją takie stany, których frekwencja wynosi $50 \%$; jest to efekt zróżnicowania technologicznego naszych dwóch naczyń. Jeśli te dwa pojemniki różnią się wielkością, to przy porównywalnym ich rozdrobnieniu (po potłuczeniu) i przeanalizowaniu poszczególnych fragmentów, frekwencje pierwotnie 50-procentowe ulegną poważnym zmianom, znacznie powyżej albo poniżej 50\%. Rozbieżności te będą tym większe, im znaczniejsze będzie zróżnicowanie w wielkości naczyń. Przedstawmy to w wyobrażalnych liczbach. Niech nasze naczynia mają formę kuli, a objętość jednego niech będzie dwa razy większa od drugiego. Wówczas, przy rozdrobnieniu obu naczyń na fragmenty o takiej samej powierzchni, początkowa frekwencja stanów cech po $50 \%$ zmieni się i wynosić będzie odpowiednio około 62 i około 38\%. Przy na przykład dziesięciokrotnej różnicy w objętości naszych fikcyjnych kulistych naczyń frekwencje te zmienią się odpowiednio do około 82 i 18\%. Można by wówczas wyciągnąć niewłaściwy wniosek, że jedna z receptur stosowana była ponad czterokrotnie częściej niż druga. Ciekawie może się też na przykład przedstawiać rozkład średniej grubości ścianek. Pierwotnie mielibyśmy tylko dwie grubości, po potłuczeniu może ich być cała gama. W przypadku zbioru większego, złożonego z kilkudziesięciu czy kilkuset naczyń zróżnicowanych w formach i kruchości (nierównomiemość rozdrobnienia), sytuacja skomplikuje się bardziej. Oczywiście w naszym logicznym eksperymencie możemy dociec, w jakim stopniu wyniki są przekłamane. Wystarczy przeanalizowane fragmenty skleić w całe naczynia, te poddać badaniom i porównać wyniki. W praktyce archeologicznej, gdzie mamy do czynienia z realnymi pradziejowymi zbiorami fragmentów ceramiki, zabiegi takie nie są możliwe do przeprowadzenia. Przekonał się o tym każdy analityk ceramiki. O niektórych przyczynach takiego stanu rzeczy wspomnę nieco później.

Zmianie mogą ulegać także frekwencje stanów cech morfologicznych i zdobniczych. Dobrym przykladem ilustrującym taki stan bezpośrednio na zbiorach pradziejowych może być porównanie udziału procentowego fragmentów zdobionych w całym zbiorze skorup do procentowego udziału takich fragmentów w zbiorze fragmentów brzegów dla ceramiki ze stanowisk kultury pucharów lejkowatych, zwłaszcza z jej wczesnych faz. Zasadniczo naczynia $z$ tego okresu były zdobione bardzo ubogo, niemal wyłącznie w strefie podkrawędnej. Jednocześnie niemal zawsze, gdy naczynie było zdobione, posiadało zdobienia nakrawędne lub podkrawędne. Liczbę różnych brzegów można potraktować jako najmniejszą liczbę naczyń, od których pochodzi zbiór ceramiki, zaś udział w nich brzegów zdobionych powinien być zbliżony do realnej liczby naczyń zdobionych. Dla osad z wczesnych faz kultury pucharów lejkowatych z Kujaw i z ziemi chełmińskiej udział fragmentów zdobionych w całych zbiorach ceramiki wynosi zaledwie około 1-5\%, zaś udział brzegów zdobionych w podzbiorze wszystkich brzegów około 30-50\%. Sądzę, że 
z perspektywy poruszanej tu problematyki przykładu tego nie trzeba komentować. Wystarczy wskazać, że wraz ze wzrostem wyklejalności ceramiki wskaźnik intensywności zdobienia (1-5\%) będzie się zbliżał do wskaźnika brzegów zdobionych (30-50\%), osiągając go po wyklejeniu wszystkich fragmentów ceramiki w pełne naczynia.

\section{STRUKTURA UŻYTKOWA A STRUKTURA ZDEPONOWANA}

Deformacje w charakterystyce ceramiki użytkowanej jednorazowo zostały też spowodowane działalnością kulturową dawnych społeczności. Nie wszystkie użytkowane naczynia po potłuczeniu deponowane były w obrębie osady. Odnosi się to w szczególności do pojemników doraźnie używanych poza osadą i tam zniszczonych lub do naczyń użytku codziennego deponowanych w celach szczególnych poza osadą ( $n$ p. w celach wotywnych lub pogrzebowych). Jednocześnie nie wszystkie naczynia „dożywały” swoich dni w osadzie, w której były wykonane i pierwotnie używane. W przypadku zmiany miejsca zamieszkania część naczyń przenoszono do nowej osady. Poważny argument przemawiający za przenoszeniem części naczyń w nowe miejsce znajdujemy w charakterystyce ceramiki kultury pucharów lejkowatych. Charakteryzuje się ona powszechnym stosowaniem komponentu nieplastycznego schudzającego masę ceramiczną w postaci tłucznia ceramicznego. Zatem zakładając nową osadę przynoszono z poprzedniej całe naczynia bądź przynajmniej ich fragmenty (na domieszkę). Nie znamy kryteriów przeznaczania ceramiki do tej swoistej utylizacj i nie wiadomo, czy były to jakieś specyficzne pojemniki, czy też przypadkowe fragmenty naczyń.

Użytkowany zestaw naczyń był dynamiczny. Poszczególne pojemniki wypadały z obiegu i zastępowane były przez inne. Ze względu na jakość i sprawowane funkcje zróżnicowane było przeciętne ,życie naczyń". Jest to zjawisko porównywalne z naszą rzeczywistością, w której użytkujemy niemałe ilości przedmiotów ceramicznych, tłukących się i trafiających koniec końców do śmietnika. Przeciętne życie talerza z zastawy codziennej jest krótsze od tego z odświętnej. Życie ozdobnego wazonu jest przeciętnie znacznie dłuższe od życia innych pojemników. Z takich właśnie powodów struktura ceramiki z naszego domowego śmietnika wcale nie odpowiada strukturze aktualnie użytkowanej. Pewne typy naczyń ze śmietnika proporcjonalnie będą nadreprezentowane, ilość innych w proporcjach będzie niedoszacowana. Spróbujmy wyobrazić to sobie przez liczby. Załóżmy, że w naszym domowym serwisie mamy trzy typy naczyń: A, B i C. Ich liczby są następujące: 3 naczynia A, 2 naczynia B i 1 C. Średni czas użytkowania naczynia A wynosi jedną jednostkę czasową, naczynia $\mathrm{B}$ - dwie takie jednostki i naczynia $\mathrm{C}$ - trzy jednostki. Po sześciu jednostkach czasu zdeponowaniu ulegną fragmenty 18 naczyń typu A, 6 naczyń B i 2 naczyń C. Początkowe proporcje użytkowe 3:2:1 zmieniły się w proporcje zdeponowane 9:3:1. Przy odwróceniu średniego czasu życia poszczególnych naczyń (A - 3 jednostki czasowe, B - 2 jednostki i $C-1$ jednostka), po 6 jednostkach czasowych zdeponowaniu ulegną szczątki 6 naczyń typu A, 6 - typu B i 6 - typu C, a więc użytkowe proporcje 3:2:1 zmienią się na zdeponowane $1: 1: 1$. Proporcje zdeponowane 
zachowane będą w dowolnie długim czasie, jeśli reguły użytkowania i - co za tym idzie - średnie życie naczyń oraz ich użytkowe relacje ilościowe nie ulegną zmianie. Przykłady te dobrze ilustrują ilościową nieadekwatność struktury użytkowanej do zdeponowanej.

Nasz śmietnik jest strukturą kształtowaną w krótszym lub dłuższym czasie, w jakim mogły pojawiać się innowacje w użytkowanym zestawie naczyń. Mogły więc pojawiać się elementy nowe, inne mogły zanikać. Zatem zdeponowany zbiór ceramiki jakościowo i ilościowo charakteryzuje nie jakąś konkretną, jednorazową rzeczywistość, lecz przez wiele lat kumulowany śmietnik. Z perspektywy neolitu ów śmietnik nie musi stanowić jednego, przestrzennie ograniczonego miejsca. Deponowanie śmieci było nierównomierne w obrębie całej osady. Część pozostawała na powierzchni, stając się na przykład elementem kształtujących się warstw kulturowo-geologicznych. Inne trafiały w miejsca specjalnie do tego przeznaczone, znajdujące się bądź to na powierzchni gruntu, bądź w zagłębieniach naturalnych lub sztucznych (jamy śmietniskowe specjalnie do tego wykopane bądź wykorzystane wtórnie wcześniejsze jamy gospodarcze). Może to stwarzać dodatkowe problemy. Zróżnicowanie charakterystyk materiałów znajdowanych w skupieniach (w tzw. warstwach i obiektach) może być spowodowane odmiennościami funkcjonalnymi różnych miejsc, różnicami w czasie deponowania bądź nierównomiernym procesem deponowania - w sensie czasowym lub jakościowym (różny czas deponowania w poszczególnych miejscach; selektywne deponowanie fragmentów pewnych naczyń w ściśle określonych miejscach). Jest to wlaściwe miejsce, w którym warto wspomnieć o problematyce homogeniczności wydobytych przez archeologa materiałów zabytkowych. Jest to dodatkowy aspekt poruszanej tu problematyki. Kwestii homogeniczności, ze względu na złożoność problemu, nie będę tu dalej rozwijal.

\section{STRUKTURA ZDEPONOWANA A STRUKTURA ARCHEOLOGICZNA}

Wróćmy do tematu zasadniczego. Ostatni poruszany tu wątek przenosi nas w odrębną problematykę - dekompletacji i dekompozycji podepozycyjnej. Różne miejsca depozycji w różnym stopniu narażają ceramikę na procesy niszczenia, jakie zachodziły od momentu wyrzucenia stłuczki ceramicznej do momentu badań archeologicznych. Ceramika leżąca na powierzchni narażona była na niszczenie jeszcze w trakcie użytkowania osady. Zdeponowany zestaw dekompletowały też procesy późniejsze - orka, nadmierne namiękanie i przesuszanie, przepłukiwanie, mróz itp. Największe szanse na przetrwanie miała ceramika znajdująca się najgłębiej, w tzw. wziemnych obiektach kulturowych. Wymienione zjawiska i rodzaj środowiska, w którym zdeponowano ceramikę (jak poziom kwasowości gruntu) powodowaly inną jeszcze formę dekompletacji, dla badaczy groźniejszą. Pewne receptury technologiczne stanowiły zagrożenie dla przetrwania wykonanej w nich ceramiki. Ceramika krucha bądź słabo wypalona narażona była na niszczenie przez procesy mechaniczne. One także niszczyły ceramikę zdeformowaną przez procesy chemiczne (np. po rozłożeniu w kwaśnym podłożu muszli użytych jako domieszka 
schudzająca masę ceramiczną). Tego rodzaju procesy niszczące mogą zakłócić strukturę ceramiki w nieobliczalnym stopniu. W skrajnych przypadkach mogło dojść do całkowitego zaniku (zniszczenia) pewnych grup ceramiki, a więc zaniku pewnych jakości, reprezentowanych nawet dość licznie w deponowanym materiale. Dobrym przykładem są tu często spotykane różnice w jakości i ilości stanów cech ceramiki, pochodzącej z jednego stanowiska, pozyskanych w trakcie badań powierzchniowych i wykopaliskowych. Jeszcze częstszym zjawiskiem, potwierdzającym zaprezentowane procesy, jest niemal powszechnie obserwowane zróżnicowanie w rozdrobnieniu ceramiki - znacznie większe rozdrobnienie na powierzchni stanowiska i we współczesnej warstwie ornej od występującego w tzw. szerokopłaszczyznowych warstwach i zwłaszcza wziemnych obiektach kulturowych. Większe rozdrobnienie bardziej naraża na całkowite zniszczenie ceramikę bardziej podatną.

Odrębnym zjawiskiem dekompletacji podepozycyjnej są procesy przemieszczania fragmentów ceramiki, na przykład przez procesy denudacyjne. Większość warstw kulturowych nie ukształtowala się w okresie osadnictwa, lecz znacznie później, na przyklad wskutek późniejszej orki. Bez wątpienia musiało niekiedy dochodzić do spłukiwania po stoku poziomów glebowych i niekiedy zabytków. Z jednej strony zachodziły zatem zjawiska niszczące, $\mathrm{z}$ drugiej - można by rzec - istniały pewne zasady preferencji denudacyjnej. Ceramika slabo poddająca się denudacji wydobywana była na powierzchnię i tam podlegała procesom niszczącym (omówionym wcześniej).

\section{DYSKUSJA}

Dochodzimy wreszcie do podsumowania przedstawionych rozważań. Wszelkie wymienione dotychczas procesy dotyczące użytkowania naczyń, deponowania ich fragmentów i niszczenia w procesach podepozycyjnych w nieobliczalny sposób deformują to, co zachodziło w procesie kulturowym. Ponadto w różnych miejscach tempo i nasilenie tych procesów mogły być odmienne. Nasze archeologiczne analizy i opisy nie dotyczą struktur ongiś użytkowanych. Archeolog ma do czynienia z ceramiką, której obraz uległ zniekształceniu już w procesie deponowania, które odbywało się w bliżej nieokreślonym czasie. Długi okres deponowania powiększał poziom dekompletacji. To co poznajemy było dodatkowo przekształcane i dekompletowane przez różne procesy podepozycyjne. Zakres zmian zachodzących pomiędzy użytkowaniem naczyń a wydobyciem ich fragmentów przez archeologa jest niemożliwy do określenia. Te bolesne prawdy, jak się wydaje, nie są uświadamiane przez wielu archeologów, a ich akceptacja ma zasadniczy wpływ na przedsięwzięcia składające się na proces poznawczy i pojawiające się w jego efekcie hipotezy.

Poczynione uwagi uświadamiają problemy związane z analizą opisową poszczególnych zbiorów ceramiki i analizą porównawczą pomiędzy nimi. Najbardziej dyskomfortowa jest dekompletacja powstała w procesach podepozycyjnych. Niemal wszystkie badane wykopaliskowo stanowiska neolityczne z Niżu Polskiego typowano do takich prac 
na podstawie odkryć ceramiki na ich powierzchni. Koronnym argumentem na niewyobrażalną dekompletację ceramiki jest jej słaba „wyklejalność” po wydobyciu. Dekompletacja jest szczególnie widoczna przy obserwacji brzegowych i zarazem zdobionych fragmentów ceramiki kultury pucharów lejkowatych. Możliwe jest tam wiarygodne przyporządkowanie skorup do poszczególnych naczyń. Często okazuje się, że dysponujemy zaledwie pojedynczym, drobnym fragmentem brzegowym, stanowiącym najwyżej kilka procent całego obwodu wylewu naczynia. Sytuacje takie są powszechne zarówno na stanowiskach badanych fragmentarycznie, jak i tych zbadanych niemal w całości. Dotyczy to także fragmentów naczyń, dla których obecnie obserwowane stany cech technologicznych sugeruja pierwotną znaczną trwałość i odporność na zniszczenie. Pytanie o przyczyny tak znacznej dekompletacji nasuwa się automatycznie. Skala zniszczenia wielu stanowisk (np. zachowanie się zaledwie przydennych partii obiektów wziemnych) wyraźnie sugeruje, że zasadniczą przyczyną takiego stanu rzeczy są właśnie procesy podepozycyjne, zarówno te, które zachodziły jeszcze w trakcie trwania zasiedlenia (np. rozdrabnianie i calkowite „mielenie” fragmentów zdeponowanych na powierzchni w obrębie obejścia), jak i później (np. w efekcie późniejszej orki). W przypadku dekompletacji ceramiki kultury pucharów lejkowatych (może także i innej) braki znaczących fragmentów naczyń można też tłumaczyć procesami kulturowymi - tłuczeń ceramiczny przeznaczony zostal na domieszkę schudzającą masę ceramiczną .

Godząc się z całą realną czy tylko domniemaną rzeczywistością archeologiczną, analizując ceramikę - bez względu na to, czemu by to miało służyć - musimy przyjąć bądź odrzucić kilka podstawowych hipotez. Bez znaczenia jest tu fakt, czy ceramikę lub jakiekolwiek inne pozostałości działalności kulturowej traktujemy jako źródło lub przedmiot poznania czy też wyłącznie jako środek służący kreowaniu własnej refleksji na temat wytwórców i użytkowników zjawisk materialnych, których pozostałości odkrywamy. Aby owe pozostałości, w tym również ceramiczne, były przydatne do czegokolwiek, musimy przyjąc na początek trzy hipotezy:

1) hipotezę o homogeniczności odkrytych pozostałości działalności kulturowej;

2) hipotezę o reprezentatywności odkrytych pozostałości działalności kulturowej ze zbadanej części stanowiska dla całego stanowiska - chodzi tu wyłącznie o reprezentatywność względem obecnych struktur archeologicznych;

3) hipotezę o reprezentatywności odkrytych pozostałości działalności kulturowej dla struktury zdeponowanej - chodzi tu wyłącznie o zakres przedmiotowy, określony przez odkrywane pozostałości, a nie o całokształt struktury zdeponowanej; w przypadku ceramiki chodzi wyłącznie o strukturę zdeponowanych fragmentów naczyń, a nie o całe naczynia, których fragmenty zostały zdeponowane.

Hipotezy te powinny być przyjęte dla całego stanowiska archeologicznego lub jego określonych fragmentów zdefiniowanych przestrzennie lub chronologicznie. Mogą też

Zasadniczo niewiele wiemy o stosowaniu takiej domieszki w ceramice, która zawiera domieszki mineralne (wiadomo, że bywala stosowana). Stan taki wynika z trudności identyfikacji makroskopowej, braku analiz specjalistycznych oraz braku zainteresowania archeologów. 
być przyjęte jedynie dla wybranych kategorii pozostałości działalności kulturowej, na przykład dla ceramiki. Zaprezentowany tekst jednoznacznie wskazuje, że przyjęcie wymienionych hipotez nie może się odbywać automatycznie. Nie wydaje się też możliwe określenie takiej metody (metod), której zastosowanie prowadziłoby do jednoznacznej odpowiedzi na pytanie o prawdziwość bądź fałszywość naszych hipotez. Warto też zauważyć, że odrzucenie którejś z trzech hipotez nie pociąga za sobą odrzucenia pozostałych. Fakt taki powodowałby jednak nieprzydatność lub przynajmniej znaczne ograniczenie przydatności odkrywanych pozostałości działalności kulturowej dla wypowiadania się w zakresie problematyki podejmowanej przez archeologów. Dotyczy to także ceramiki.

Rozważania na temat ceramiki prowadzą do refleksji ogólniejszej. Warto zastanowić się nad faktem, że pozostałości działalności kulturowej znajdowane w obrębie tzw. osady mają w rzeczywistości charakter „osadowiska” (pozostalości po osadzie lub osadach $)^{6} \mathrm{w}$ odniesieniu do struktur tzw. warstw kulturowych oraz kulturowych obiektów wziemnych i zasadniczo charakter "gruzowiskowy” lub śmietniskowy w odniesieniu do zabytków ruchomych w nich występujących. Z perspektywy zabytków ceramicznych trzeba zastanowić się nad problemem wartości przedmiotów zachowanych w śmietniskach i ich współczesnych opisów w poznawaniu przeszłości ${ }^{7}$. Wiemy bowiem, że nasze postrzeganie (i opisywanie) zabytków ceramicznych ma się nijak do postrzegania naczyń ceramicznych przez dawnych wytwórców i użytkowników. Stąd nasze opisy nie mogą stanowić żadnych bezpośrednich podstaw do rekonstrukcji dawnych czynności kulturowych. Wiemy też, że opisywana przez nas jakościowa i ilościowa struktura wydobytych fragmentów naczyń z dawnych osad ma się nijak do struktury użytkowanej i odległa jest od tej, w trakcie trwania osady (osad), zdeponowanej. Wobec takiego stanu rzeczy jedyne obiektywne stwierdzenie jest takie, że w jakiejś przeszłości wytworzono takie, a nie inne naczynia (opisane w kategoriach archeologicznych), w danym miejscu je użytkowano i po zniszczeniu ich fragmenty zdeponowano jako śmieci. Wnioski tego typu są jednak dość banalne. Wszelkie inne wywody, w których wykorzystuje się w jakikolwiek sposób opisy (analizy) ceramiki pochodzącej z pozostałości po osadach, u swych podstaw mają indywidualne przekonania

\footnotetext{
${ }^{6}$ Ten neologizm wprowadziłem na zasadzie analogii do funkcjonujących $w$ archeologii terminów określających pozostałości cmentarzy czy grodów. Archeolodzy w swych pracach prezentują opisy cmentarzysk i grodzisk oraz osad. Tymczasem termin ,osada" odnosi się raczej do struktury funkcjonującej. W odniesieniu do struktur dawnych można by go używać jedynie w przypadkach prowadzenia zabiegów rekonstrukcyjnych. W takich sytuacjach powinniśmy też używać terminów „cmentarz” i „gród”.

${ }^{7}$ Problem ten dotyczy nie tylko ceramiki. Warto tu zadać pytania o wartość informacyjną struktury śmietniskowej zabytków krzemiennych i kamiennych (jak się wydaje, słabo poddających się niszczącym procesom podepozycyjnym). Równie ciekawie wygląda na przyklad problem udziału w życiu dawnych wspólnot przedmiotów metalowych (w przypadku neolitu - miedzianych). Archeolodzy wypowiadając się o skali użytkowania takich przedmiotów skłonni są do odwoływania się do liczby znalezisk. Tymczasem w strukturach śmietniskowych są one wyjątkowo rzadkie. Skali użytkowania nie muszą też odzwierciedlać znaleziska grobowe czy depozytowe. Dobrym tego przykładem jest nasza rzeczywistość. Ile - populamych przecież złotych obrączek znajdziemy na wysypisku śmieci czy nawet w grobach? Czy liczba aluminiowych puszek znalezionych na wysypisku śmieci odzwierciedla skalę ich użytkowania?
} 
badacza $^{8}$. Przekonania te wyrastają z przyjmowanych koncepcji z zakresu teorii kultury i odnoszą się do problemów, które warto i można rozwiązywać, oraz do metod, które pozwalają skutecznie problemy te rozwiązywać. Żałować należy, że archeolodzy wykorzystujący w rozważaniach zabytki ceramiczne prezentują swe przekonania wyjątkowo rzadko. Rzadko też można znaleźć jakąkolwiek refleksję dotyczącą wymienionych wcześniej hipotez, które przyjmowane są po cichu i zapewne w wielu przypadkach niesłusznie. Odnieść też można wrażenie, że archeolodzy przyjmują często jeszcze dwie $\mathrm{i}$ to całkowicie błędne hipotezy, że im szczególowszy będzie stosowany przez nich opis ceramiki, tym bardziej zbliżony on będzie do obiektywnego, oraz że opisywana struktura zbiorów fragmentów ceramiki zbliżona jest do jednorazowej struktury użytkowej całych naczyń.

\section{BIBLIOGRAFIA}

Kowalski A.P

2000 Genealogia sztuk II. Naczynie w stowniku kultury ., nostratyckiej". Analiza magicznego doświadczenia rzeczy [Zus.: Genealogie der Kunst II. Gefasse im Wortschatz der ,nostratischen Kultur”. Analyse magischer Sacherfahrung], (w:) H. van den Boom, A.P. Kowalski, M. Kwapiński (red.), Kultura archaiczna w zwierciadle wyobrażen, slów i rzeczy, Gdańsk, s. 149-166.

Mierzwiński A.

2002 Klopoty z ceramikq jako ,źródlem poznania" [Zus.: Schwierigkeiten mit der Keramik als einer „Erkenntnisquelle"], „Przegląd Archeologiczny” t. 50, s. 71-83

Nowak M.

1996 Ceramika kultury pucharów lejkowatych ze stanowiska 1 w Kawczycach [Sum.: The pottery of the Funnel Beaker Culture from site 1 in Kawczyce], Kraków.

Stolpiak B.

1988 Metodologiczne problemy badan kontaktów spoleczeństw pradziejowych, (w:) Kontakty pradziejowych spoleczenstw Kujaw z innymi ludami Europy, red. A. Cofta-Broniewska, Inowroclaw. s. $11-14$

\section{ARCHAEOLOGICAL COMPOSITION OF POTTERY ASSEMBLAGES FROM NEOLITHIC SETTLEMENTS}

\section{S u m m a ry}

Analyses of pottery assemblages from Neolithic settlements are a backbone of prehistoric archaeology and provide scholars with empirical basis for further investigations (e.g. distinguishing archaeological cultures. their regional groups, phases, ethic issues, etc.). Hence, there is a problem of relationship between contemporary archaeological assemblage with its distinctive traits and pottery assemblages in the past. Technological

${ }^{8}$ Dotyczy to m.in. tak popularnych $w$ archeologii neolitu kwestii, jak: archeologiczne podziały kulturowe i wewnątrzkulturowe (fazy rozwojowe, grupy terytorialne) oraz przyporządkowanie do nich zabytków ceramicznych, ustalanie chronologii relatywnej na podstawie cech technologicznych i stylistycznych, identyfikacja elementów nowych bądź obcego pochodzenia i wyprowadzane stąd wnioski, problematyka genezy wydzielanych zjawisk kulturowych lub styli ceramicznych, określanie jedno- lub wielofazowości zasiedlenia itp. 
recipes, as studied by archaeologists, do not conform to a totality and complexity of prehistoric technological process. In particular, this refers to a set of features identified by producer from one side and archaeologist from the other. Actual production recipes were depended upon producer's beliefs, often different from those of archacologist. Additionally, it is impossible to define an attitude of prehistoric actors to pottery vessels they used. Having these evident remarks in mind, the article is intended to address an adequacy of archaeological accounts about pottery assemblages in relation to potential scope of pottery usage at Neolithic settlements. It is argued that these two accounts, referring to such far distanced realities, are incomparable. This is due to a number of reasons.

Description of a complete vessels' technology, morphology and decoration is different from that of pottery sherds resulted from its breakage. In particular, this refers to frequency of particular attributes. In many cases, however, this comprises also qualitative differences. It is caused by differences in vessels size and dissimilarity in fragmentation of different types of vessels.

"Life span" of different vessels was diverse in the past, as it is today. It results in overrepresentation of some types of vessels and underestimation of others in refuse heaps (pottery found at prehistoric settlements is to be treated as refuse). Moreover, complete vessels or their fragments may have been deposited outside the settlement (e.g. in burials or were taken to new settlements) or used as a temper for production of new pots. Consequently, a composition of pottery deposited at prehistoric settlement (as refuse) does not reflcct a composition of vessels used in any given moment in the past.

It is worth mentioning that composition of deposited pottery sherds was further modified by postdepositional processes extended over millennia. Consequently, some of their original attributes were transformed, their fragmentation increased while some other parts completely disappeared (as a result of diverse chemical and physical processes).

Accordingly, a quantitative and qualitative composition of excavated pottery fragments from prehistoric settlements reflect neither a composition of pottery vessels used at any given moment at the settlement nor even an assemblage deposited during its exploitation. These evident conclusions, however, must lead to more serious reflections on heuristic potential of analysed assemblages. Usefulness of this category of data is to be debated if we want to go beyond quite banal statements such as certain kinds of pottery (as defined by archaeology) were produced in the past, they were later used and finally deposited as refuse. 